\title{
Pengaruh jam kerja, modal, pendidikan dan tenaga kerja terhadap pendapatan UKM sektor perdagangan di Kota Sungai Penuh
}

\author{
Yogi Seprianto; *Zulfanetti; Nurhayani \\ Prodi Ekonomi Pembangunan, Fakultas Ekonomi dan Binsis, Universitas Jambi \\ *E-mail korespodensi: zulfa_netti@unja.ac.id
}

\begin{abstract}
The purpose of this study was to determine the effect of capital, working hours, education, social and economy simultaneously on increasing income Trade Sector UKM in Sungai Penuh City and to know the social and economic development of UKM Trade sector in Sungai Penuh City. This research is a research with a quantitative approach with a population of 157 SMEs. The sampling technique used is proportionate stratified random sampling in order to obtain a total sample of 113 samples. The data collection technique used a questionnaire. Classical assumptions use normality test, multicollinearity test and heteroscedasticity test. The data analysis technique to answer the hypothesis uses multiple linear regression analysis techniques. The results of the assumptions are. Social development affects the income of trading SMEs in Sungai Penuh City. variable working hours, capital, education, and labor have a significant effect on the income of trading SMEs in Sungai Penuh City partially. The four variables, namely working hours, education capital, and labor have an effect on the income of trading SMEs in Sungai Penuh City.
\end{abstract}

Keywords: Capital, education, income. labor, and work hours

\begin{abstract}
Abstrak
Tujuan dari penelitian ini untuk mengetahui adanya pengaruh modal, jam kerja, pendidikan, dan Tenaga Kerja secara bersamaan terhadap pendapatan UKM Sektor Perdagangan di Kota Sungai Penuh dan untuk mengetahui perkembangan sosial dan ekonomi UKM Sektor perdagangan di Kota Sungai Penuh. Penelitian ini merupakan penelitian dengan pendekatan kuantitatif dengan jumlah populasi sebanyak 157 UKM. Teknik pengambilan sampel menggunakan proportionate stratified random sampling sehingga didapat jumlah sampel sebanyak 113 sampel. Teknik pengambilan data menggunakan kuesioner. Asumsi klasik menggunakan uji normalitas, uji multikolinieritas dan uji heterokedastisitas. Teknis analisis data untuk menjawab hipotesa menggunakan teknis analisis regresi linier berganda. Hasil dari asumsi yaitu. Perkembangan sosial berpengaruh terhadap pendapatan UKM perdagangan di Kota Sungai Penuh. variabel jam kerja, modal, pendidikan, dan tenaga kerja berpengaruh signifikan terhadap pendapatan UKM perdagangan di Kota Sungai Penuh secara parsial. Keempat variabel tersebut yaitu jam kerja,modal pendidikan, dan tenaga kerja berpengaruh terhadap pendapatan UKM perdagangan di Kota Sungai Penuh
\end{abstract}

Kata kunci: Jam kerja, modal, pendidikan, tenaga kerja, dan pendapatan 


\section{PENDAHULUAN}

Perencanaan pembangunan (development planning) adalah suatu bentuk perencanaan yang berkaitan dengan upaya meningkatkan pertumbuhan tingkat ekonomi dan kesejahteraan masyarakat (Hariyono, 2010). Tidak dapat dipungkiri, Indonesia sebagai negara yang sedang berkembang tidakdapat terlepas dari kegiatan perencanaan pembangunan. Dari masa ke masa, ternyata Negara Indonesia telah mengalami perubahan paradigma dalam perencanaan pembangunan.Setidaknya sejak dimulainya era reformasi, paradigma perencanaan pembangunanberganti dari perencanaan komprehensif menjadi perencanaan strategis. Paradigma perencanaan strategis dipilih oleh pemerintah karena dirasa memiliki manfaat yang jelas dalam jangka waktu yang singkat (Hariyono, 2010).

Semakin maju suatu Negara semakin banyak orang yang terdidik, dan banyak pula orang menganggur, maka semakin dirasakan pentingnya dunia wirausaha. Pembangunan akan lebih mantap jika ditunjang oleh wirausahawan karena kemampuan pemerintah sangat terbatas. Pemerintah tidak akan mampu menggarap semua aspek pembangunan karena sangat banyak membutuhkan anggaran belanja, personalia, dan pengawasannya. Oleh sebab itu, wirausaha merupakan potensi pembangunan, baik dalam jumlah maupun dalam mutu wirausaha itu sendiri. Dengan ada niat atau keinginan untuk berwirausaha akan menjadi sebuah loncatan setidaknya sebagai sebuah harapan terwujudnya pemerataan pembangunan dan kesejahteraan masyarakat. Banyak faktor psikologis yang membentuk sikap negative masyarakat sehingga mereka kurang berminat terhadap profesi wirausaha, antara lain sifat agresif, ekspansif, bersaing, egois, tidak jujur, kikir, sumber penghasilan tidak stabil, kurang terhormat, pekerjaan rendah, dan sebagainya. Pandangan semacam ini dianut oleh sebagian besar penduduk, sehingga mereka tidak tertarik. Tidak seperti layaknya etnis Cina yang terkenal sebagai wirausahawan yang rajin dan terampil, tetapi itu tidak menjadi sebuah patokan bahwa orang pribumi atau orang Indonesia tidak memiliki keterampilan hanya saja orang Indonesia tidak berani mengambil resiko dalam berdagang, terutama pada zaman sekarang ini zaman semakin maju kita dituntut untuk selalu kreatif dan inovatif tetapi kurang kesadaran tersebut menyebab Indonesia tertinggal dengan negara-negara dalam hal perekonomian negara (Alma, 2008 ).

Data dari Kementerian Koperasi dan Usaha Kecil Menengah pada tahun 2015, terdapat sekitar 57,8 juta pelaku UMKM di Indonesia. Di 2015 serta beberapa tahun ke depan diperkirakan jumlah pelaku UMKM akan terus bertambah. UMKM mempunyai peran penting dan strategis dalam pembangunan ekonomi nasional. Selain berperan dalam pertumbuhan ekonomi dan penyerapan tenaga kerja, UMKM juga berperan dalam mendistribusikan hasil-hasil pembangunan. Selama ini UMKM telah memberikan kontribusi pada Produk Domestik Bruto (PBD) sebesar 57-60\% dan tingkat penyerapan tenaga kerja sekitar 97\% dari seluruh tenaga kerja nasional (Profil Bisnis UMKM oleh LPPI dan BI tahun 2015).

UKM merupakan suatu peluang usaha ekonomi produktif yang dilakukan oleh orang perorangan atau badan usaha dalam rangka meningkatkan pendapatan, UKM sangat berperan dalam mendorong laju pertumbuhan ekonomi dan menyerap tenaga kerja. Kinerja usaha kecil dan menengah di Kota Sungai Penuh terus mengalami peningkatan baik secara kualitas maupun kuantitas. Semakin banyak jumlah UKM non BPR/LKM akan menunjukan semakin besar kapasitas pelayanan pendukung yang dimiliki daerah dalam meningkatkan ekonomi daerah melalui UKM. Pada tahun 2019 jumlah UMKM yang terdata di Kota Sungai Penuh sebanyak 8.772 UMKM yang tersebar di 8 kecamatan (Dinas Koperasi dan UKM Sungai Penuh, 2020). 
Adapun data jenis dan jumlah UKM Kota Sungai Penuh tahun 2017- 2019 dan kontribusi UKM terhadap kesejahteraan masyarakat yang diukur dari perolehan pendapatan setiap tahunnya baik untuk pemiliknya maupun karyawan di Kota Sungai Penuh selama tahun 2017-2019 dapat dilihat dari Tabel 1. dibawah ini:

Tabel 1. Kontribusi UKM terhadap Kesejahtraan Masyarakat di Kota Sungai Penuh

\begin{tabular}{cccccc}
\hline Tahun & $\begin{array}{c}\text { Jumlah } \\
\text { UKM }\end{array}$ & $\begin{array}{c}\text { Jumlah } \\
\text { pemilik } \\
\text { UKM }\end{array}$ & $\begin{array}{c}\text { Rata-Rata } \\
\text { Pendapatan } \\
\text { Pemilik/bulan } \\
\text { (jt) }\end{array}$ & $\begin{array}{c}\text { Jumlah } \\
\text { Tenaga } \\
\text { Kerja (org) }\end{array}$ & $\begin{array}{c}\text { Rata-Rata } \\
\text { Pendapatan } \\
\text { Tenaga } \\
\text { Kerja/bulan (Rb) }\end{array}$ \\
\hline 2019 & 157 & 157 & 10 & 678 & 850 \\
2018 & 199 & 199 & 7 & 489 & 600 \\
2017 & 75 & 75 & 5,5 & 346 & 450 \\
2016 & 52 & 52 & 4,5 & 285 & 380 \\
2015 & 37 & 37 & 3,8 & 200 & 250 \\
\hline
\end{tabular}

Sumber : Dinas Koperasi dan UKM Sungai Penuh, 2020

Berdasarkan latar belakang penelitian, yang menjadi rumusan masalah dalam penelitian ini adalah 1) Bagaimana kondisi sosial dan ekonomi UKM sektor perdagangan di kota sungai penuh, 2) Apakah ada pengaruh jam kerja, modal, pendidikan dan tenaga kerja terhadap pendapatan ukm di kota sungai penuh.

Adapun tujuan berdasarkan uraian rumusan masalah yang telah diuraikan, maka tujuan penelitian ini yaitu: 1) Untuk mengetahui Karakteristik social ekonomi UKM sektor perdagangan di kota sungai penuh. 2) Untuk menganalisis adanya pengaruh jam kerja, modal, pendidikan, dan tenaga kerja terhadap pendaptan UKM di Kota Sungai Penuh.

\section{METODE}

Populasi dalam penarikan sampel ini adalah seluruh pelaku UKM di kota sungai penuh sektor perdagangan sebanyak $157 \mathrm{ukm}$. Teknik yang digunakan dalam penentuan sampel ini adalah teknik Accidential Sampling, yaitu teknik pengambilan sampel yang dilakukan melalui wawancara dengan bantuan kuesioner. Sampel adalah bagian dari sejumlah karakteristik yang dimilki oleh populasi yang digunakan untuk penelitian. Bila populasi besar, peneliti tidak mungkin mengambil semua untuk penelitian misal terbatasnya dana, waktu dan tenaga, maka peneliti dapat menggunakan sampel yang diambil dari dari populasi (Sujarweni, 2015). Sampel dalam penelitian ini dihitung menggunakan rumus Slovin:

Dimana :

$$
\mathrm{n}=\frac{\mathrm{N}}{1+\left(\mathrm{NX} \mathrm{e}^{2}\right)}
$$

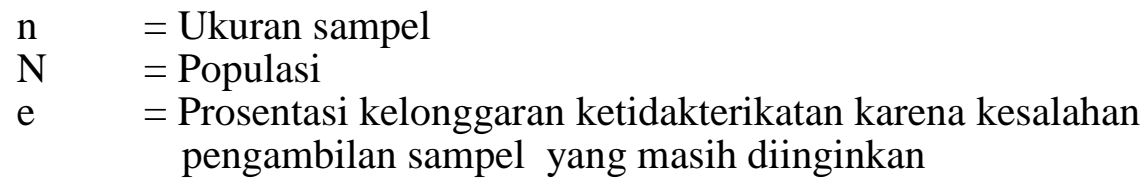




$$
\begin{aligned}
\mathrm{n} & =\frac{\mathrm{N}}{1+\left(\mathrm{N} \mathrm{X} \mathrm{e}^{2}\right)} \\
& =\frac{157}{1+\left(157 \times 0,05^{2}\right)} \\
& =112,7
\end{aligned}
$$

Jadi, sampel penelitian untuk populasi dan tingkat kepercayaan 95\% dalam penelitian ini dibulatkan menjadi 113 sampel.

\section{Analisis regresi linier berganda}

Analisis yang dilakukan untuk mengetahui pengaruh masing-masing variabel bebas terhadap variabel terikat dengan mengontrol adanya variabel bebas yang lain. Uji statistik yang digunakan adalah Regresi Linier Berganda yang digunakan untuk menjelaskan hubungan antara variabel respon yang berupa data dikotomik/biner dengan variabel bebas yang berupa data berskala interval dan atau kategorik (Ghozali, 2016) dengan persamaan sebagai berikut:

$\mathrm{Y}=\alpha+\beta_{1} \mathrm{X}_{1}+\beta_{1} \mathrm{X}_{2}+\beta_{1} \mathrm{X}_{3}+\beta_{1} \mathrm{X}_{4}+\mathrm{e}$

Dimana:

$\mathrm{Y} \quad=$ Pendapatan

$\alpha \quad=$ Konstanta

$\beta=$ Koefisien regresi

$\mathrm{X}_{1} \quad=$ Modal

$\mathrm{X}_{2} \quad=$ Jam kerja

$\mathrm{X}_{3} \quad=$ Pendidikan

$\mathrm{X}_{4} \quad=$ Tenaga kerja

\section{HASIL DAN PEMBAHASAN}

\section{Karakteristik responden Pelaku UKM sekror perdagangan}

Responden dalam penelitian ini adalah pelaku ukm sektor perdagangan di kota sungai penuh

\section{Jenis kelamin.}

Berdasarkan Tabel 1 diketahui bahwa yang menjadi sampel dalam penelitian ini adalah 66 responden laki-laki dan 47 responden perempuan.

Tabel 2. Karakteristik responden jenis kelamin

\begin{tabular}{cc}
\hline Jenis Kelamin & Frekuensi \\
\hline Laki-laki & 66 \\
Perempuan & 47 \\
\hline Jumlah & $\mathbf{1 1 3}$
\end{tabular}

Sumber: Data diolah 2021

\section{Umur}

Berdasarkan tabel diatas, diketahui bahwa yang menjadi sampel dalam penelitian ini adalah usia 20-30 tahun sebanyak 49 responden, usia 31-40 sebanyak 31 responden, usia 41-50 sebanyak 25 responden, dan usia 51-60 sebanyak 8 responden. Hal ini berarti mayoritas responden berusia 20-30 tahun. 
Tabel 3. Karakteristik responden berdasarkan umur

\begin{tabular}{rcc}
\hline & Umur & Frekuensi \\
\hline $20-30$ & & 49 \\
$31-40$ & 31 \\
$41-50$ & & 25 \\
$51-60$ & & 8 \\
\hline & Jumlah & $\mathbf{1 1 3}$ \\
\hline Rata-rata & $\mathbf{3 9 , 5 9}$
\end{tabular}

Sumber: Data diolah 2021

\section{Pendidikan}

Berdasarkan Tabel 4 diketahui bahwa yang menjadi sampel dalam penelitian ini adalah 49 responden pendidikan SMA/ SMK, 15 responden pendidikan Diploma, dan 48 responden berpendidikan S1/S2 Hal ini berarti mayoritas responden berpendidikan SMA/SMK dan S1/S2

Tabel 4. Karakteristik responden berdasarkan pendidikan

\begin{tabular}{cc}
\hline Pendidikan & Frekuensi \\
\hline SMA/SMK & 49 \\
DIPLOMA & 15 \\
S1/S2 & 49 \\
\hline Jumlah & $\mathbf{1 1 3}$
\end{tabular}

Sumber:Data diolah, 2021

\section{Jumlah modal}

Berdasarkan Tabel 5 dapat di ketahui bahwa sebanyak 17 sampel menggunakan modal sebesar 5.000.000-10.000.000, 21 sampel memiliki modal 10.000.00015.000.000 dengan, 23 sampel memiliki modal 15.000.000-20.000.000, sebanyak 19 sampel memiliki modal 20.000.000-25.000.000, modal 25.000.000-30.000.000 sebanyak 14 sampel dan modal $>30.000 .000$ sebanyak 19 sampel. Hal ini berarti ratarata pendapatan pedagang di kisaran $>15.000 .000-20.000 .000$.

Tabel 5. Karakteristik responden berdasarkan modal

\begin{tabular}{|c|c|}
\hline Modal & Frekuensi \\
\hline$>5.000 .000-10.000 .000$ & 17 \\
\hline$>10.000 .000-15.000 .000$ & 21 \\
\hline$>15.000 .000-20.000 .000$ & 23 \\
\hline$>20.000 .000-25.000 .000$ & 19 \\
\hline$>25.000 .000-30.000 .000$ & 14 \\
\hline$>30.000 .000$ & 19 \\
\hline Jumlah & 113 \\
\hline
\end{tabular}

Sumber: Data diolah, 2021

\section{Pendapatan responden}

Berdasarkan Table 6 dapat di ketahui bahwa sebanyak 15 sampel berpendapatan sebesar 3.000.000-4.500.000, 22 sampel memiliki pendapatan kisaran 4.500.0006.000.000, 24 sampel memiliki pendapatan 6.000.000-7.500.000, sebanyak 17 sampel memiliki pendapatan 7.500.000-9.000.000, pendapatan 9.000.000-10.500.000 sebanyak 13 sampel dan pendapatan $>10.500 .000$ sebanyak 22 sampel. 
Tabel 6. Karakteristik responden berdasarkan pendapatan

\begin{tabular}{lc}
\hline \multicolumn{1}{c}{ Pendapatan } & Frekuensi \\
\hline$>3.000 .000-4.500 .000$ & 15 \\
$>4.500 .000-6.000 .000$ & 22 \\
$>6.000 .000-7.500 .000$ & 24 \\
$>7.500 .000-9.000 .000$ & 17 \\
$>9.000 .000-10.500 .000$ & 13 \\
$>10.500 .000$ & Jumlah \\
\hline
\end{tabular}

Sumber: Data diolah, 2021

\section{Jam kerja responden}

Berdasarkan Tabel 7 diketahui bahwa yang menjadi sampel dalam penelitian ini adalah 16 responden yang memiliki jam kerja 4-6 jam, 78 responden memiliki jam kerja 7-9 jam, dan 19 responden memilik jam kerja kerja 10-13 jam.

Tabel 7. Karakteristik responden berdasarkan jam kerja

\begin{tabular}{cc}
\hline Jam kerja & Frekuensi \\
\hline $4-6$ & 16 \\
$7-9$ & 78 \\
$10-13$ & 19 \\
\hline Jumlah & 113
\end{tabular}

Sumber:Data diolah, 2021

\section{Tenaga kerja}

Berdasarkan Tabel 8 diketahui bahwa yang menjadi sampel dalam penelitian ini adalah 17 responden yang memiliki tenaga kerja sebanyak 1orang, 47 responden memiliki tenaga kerja sebanyak 2 orang, 33 responden memilik tenaga kerja sebanyak 3 orang, 10 responden yang memiliki tenaga kerja 4 orang, 4 responden memiliki tenaga kerja sebanyak 5 orang, dan 2 responden memiliki tenaga kerja sebanyak 6 orang.

Tabel 8. Karakteristik responden berdasarkan Tenaga kerja

\begin{tabular}{cc}
\hline Tenaga Kerja & Frekuensi \\
\hline 1 & 17 \\
2 & 47 \\
3 & 33 \\
4 & 10 \\
5 & 4 \\
6 & 2 \\
7 & 0 \\
\hline Jumlah & $\mathbf{1 1 3}$ \\
\hline
\end{tabular}

Sumber:Data diolah, 2021

\section{Uji asumsi klasik}

Pengujian asumi klasik dilakukan untuk mengetahui kondisi data yang ada agar dapat menentukan model analisis yang tepat. Untuk menguji apakah persamaan garis regresi yang diperoleh linier dan dapat dipergunakan untuk melakukan peramalan, maka harus dilakukan uji asumsi klasik yaitu: 


\section{Multikolinearitas}

Uji multikolonieritas bertujuan untuk menguji apakah dalam model regresi ditemukan adanya korelasi antar variabel bebas (Ghozali, 2016). Model regresi yang baik seharusnya tidak terjadi korelasi diantara variabel bebas. Multikolonieritas dideteksi dengan menggunakan nilai tolerance dan Variance Inflation Faktor (VIF). Tolerance mengukur variabilitas variabel bebas yang terpilih yang tidak dapat dijelaskan oleh variabel bebas lainnya. Jadi nilai tolerance yang rendah sama dengan nilai VIF yang tinggi (karena $\mathrm{VIF}=1 /$ tolerance) dan menunjukkan adanya kolinearitas yang tinggi. Nilai cutoff yang umum dipakai adalah nilai tolerance 0,10 atau sama dengan nilai VIF dibawah 10.

Hasil uji multikolinieritas untuk masing-masing variabel dapat dilihat dalam tabel dibawah ini.

Tabel 9. Hasil uji multikolinieritas

\begin{tabular}{cccc}
\hline \hline Variable & $\begin{array}{c}\text { Coefficient } \\
\text { Variance }\end{array}$ & $\begin{array}{c}\text { Uncentered } \\
\text { VIF }\end{array}$ & $\begin{array}{c}\text { Centered } \\
\text { VIF }\end{array}$ \\
\hline \hline C & $1.69 \mathrm{E}+12$ & 21.16234 & NA \\
JK & $3.53 \mathrm{E}+10$ & 32.31967 & 1.612178 \\
MODAL & 0.001364 & 10.87377 & 1.727708 \\
\hline
\end{tabular}

Sumber:Data diolah, 2021

\section{Uji normalitas}

Uji normalitas adalah pengujian tentang kenormalan distribusi variabel terikat dan variabel bebas dalam model regresi. Menurut Ghozali (2016), model regresi yang baik harus memiliki distribusi data normal atau penyebaran data statistik pada sumbu diagonal dari grafik distribusi normal. Hasil uji normalitas untuk masing-masing variabel dalam penelitian ini disajikan dalam diagram di bawah ini:

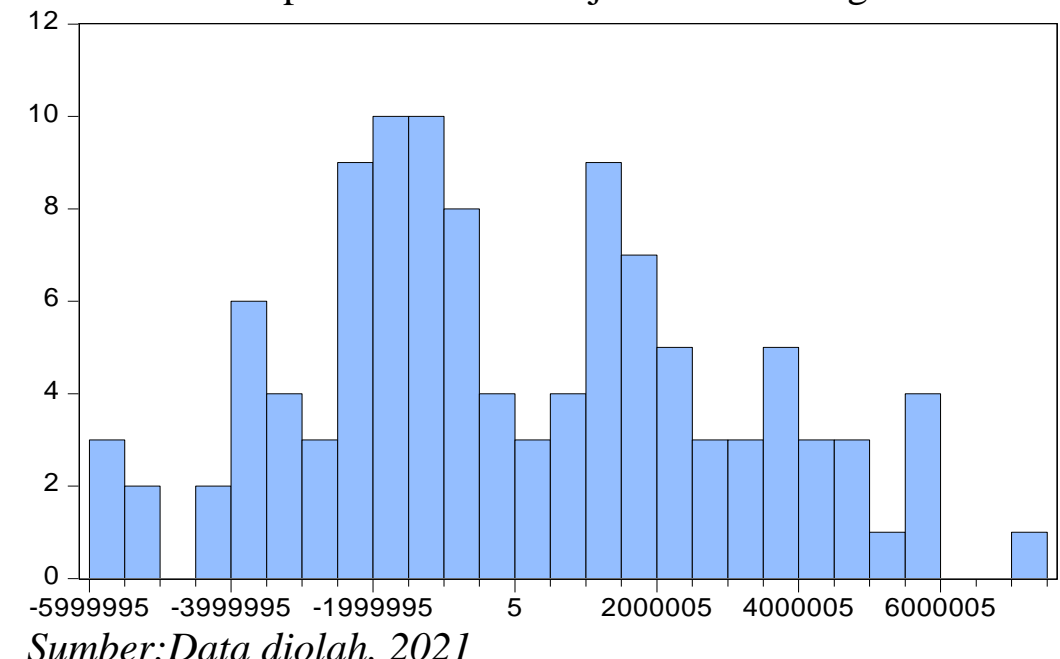

\begin{tabular}{|lc|}
\hline \multicolumn{2}{|l|}{ Series: Residuals } \\
Sample 1 112 \\
\multicolumn{2}{|l|}{ Observations 112} \\
Mean & $-2.23 e-09$ \\
Median & -524663.4 \\
Maximum & 7109567. \\
Minimum & -5973264. \\
Std. Dev. & 2931834. \\
Skewness & 0.212004 \\
Kurtosis & 2.407011 \\
& \\
Jarque-Bera & 2.479953 \\
Probability & 0.289391 \\
\hline
\end{tabular}

Gambar 1. Uji Normalitas

Berdasarkan data pada Gambar 1 dapat dilihat bahwa nilai prob. Jarque-Bera hitung sebesar $2.479953>0.05$, maka dapat disimpulkan residualnya terdistribusi secara normal dan asumsi klasik tentang kenormalan telah terpenuhi. 


\section{Uji Heteroskedastisitas}

Data yang digunakan untuk mengestimasi model regresi linier merupakan data time series maka diperlukan asumsi bebas autokorelasi. Uji ini digunakan untuk melihat ada atau tidaknya korelasi yang terjadi antara residual pada satu pengamatan dengan pengamatan lain pada model regresi.

Tabel 10. Hasil uji heteroskedastisitas

Heteroskedasticity Test: Glejser

F-statistic

0.428438 Prob. F(4,108)

0.7878

Obs*R-squared

1.765554 Prob. Chi-Square(4)

0.7788

Scaled explained SS

1.133653 Prob. Chi-Square(4)

0.8889

Sumber: Data diolah, 2021

Berdasarkan hasil data yang telah di uji menggunakan uji Glejser, dapat diketahui $\mathrm{p}$ Value yang ditunjuk dengan nilai prob.Chi-Square(4) pada Obs*R-squared yaitu sebesar 0,7788. Dengan nilai p value $0,7788>0,05(\alpha=5 \%)$ maka H0 diterima yang berarti bahwa model regresi bersifat homokedastisitas atau dengan kata lain model regresi terbebas dari gejala heterokedastisitas dengan tingkat kepercayaan $53 \%$.

\section{Regresi linear berganda}

Uji statistik regresi linier berganda digunakan untuk menguji signifikan atau tidaknya hubungan lebih dari dua variabel melalui koefisien regresinya (Sugiyono, 2017).

Tabel 11. Hasil regresi

\begin{tabular}{lccrr}
\hline \hline \multicolumn{1}{c}{ Variable } & Coefficient & Std. Error & t-Statistic & Prob. \\
\hline \hline C & -3732547. & 1767218. & -2.112104 & 0.0370 \\
JK & 369490.3 & 188587.7 & 1.959249 & 0.0527 \\
MODAL & 169509.0 & 0.037215 & 4.554824 & 0.0000 \\
PENDIDIKAN & 382115.7 & 111553.0 & 3.425417 & 0.0009 \\
TK & 595515.4 & 288057.7 & 2.067347 & 0.0411 \\
\hline \hline R-squared & 0.533276 & Mean dependent var & 10514732 \\
Adjusted R-squared & 0.515829 & S.D. dependent var & 4291504. \\
S.E. of regression & 2986132. & Akaike info criterion & 32.70047 \\
Sum squared resid & $9.54 \mathrm{E}+14$ & Schwarz criterion & 32.82183 \\
Log likelihood & -1826.226 & Hannan-Quinn criter. & 32.74971 \\
F-statistic & 30.56444 & Durbin-Watson stat & 2.368641 \\
Prob(F-statistic) & 0.000000 & & \\
\hline \hline
\end{tabular}

Sumber:Data diolah, 2021 berikut:

Berdasarkan tabel diatas, persamaan regresi linier berganda dapat disusun sebagai

$$
\begin{aligned}
\mathrm{Y}= & -33.732 .547+369.490 .3(\mathrm{JK})+169.509(\mathrm{MODAL})+382.115 .7(\mathrm{TP})+ \\
& 595.515 .4(\mathrm{TK})
\end{aligned}
$$

Koefisien variabel jam kerja (X1) sebesar 369.490.3 artinya apabila setiap kenaikan satu jam kerja maka pendapatan akan naik sebesar Rp 369.490.3 Koefisien 
bernilai positif artinya terjadi hubungan searah antara jam kerja dan pendapatan.

Koefisien modal (X2) sebesar 169.509 artinya apabila kenaikan modal satu juta maka nilai pendapatan akan naik sebesar Rp 169.509. Koefisien bernilai positif artinya terjadi hubungan searah antara modal dan pendapatan.

Koefisien variabel pendidikan (X3) sebesar 382.115.7 artinya apabila kenaikan satu tahun pedidikan maka nilai pendapatan akan naik sebesar Rp 382.115.7 Koefisien bernilai positif artinya terjadi hubungan searah antara modal dan pendapatan.

Koefisien variabel tenaga kerja (X3) sebesar 595.515.4 artinya apabila kenaikan satu orang tenaga kerja maka nilai pendapatan akan naik sebesar Rp 595.515.4 Koefisien bernilai positif artinya terjadi hubungan searah antara modal dan pendapatan.

\section{Uji t}

Uji t dilakukan untuk melihat ada tidaknya pengaruh variabel - variabel bebas (jam kerja, modal, pendidikan, dan tenaga kerja) terhadap variabel terikat (pendapatan UKM) secara parsial. Dengan ketentuan apabila tingkat signifikansi $<\alpha(0,05)$.

Berdasarkan hasil uji t (Parsial) didapatkan bahwa :

Berdasarkan hasil uji t-statistik diketahui bahwa variabel Jam kerja berpengaruh signifikan terhadap Penyerapan pendapatan dengan tingkat kepercayaan $53 \%$ dan $\alpha=5$ $\%$. Hal ini ditunjukkan dengan nilai probababilitas $0,0370<\alpha=5 \%$. Hasil regresi menunjukkan bahwa variabel Jam kerja berpengaruh signifikan terhadap Pendapatan.

Berdasarkan hasil uji t-statistik diketahui bahwa variabel Modal berpengaruh signifikan terhadap Penyerapan pendapatan. Hal ini ditunjukkan dengan probabilitas $0,0000<\alpha=5 \%$. Hasil regresi menunjukkan bahwa variabel Modal berpengaruh signifikan terhadap Pendapatan.

Berdasarkan hasil uji t-statistik diketahui bahwa variabel Pendidikan berpengaruh signifikan terhadap Penyerapan Pendapatan. Hal ini ditunjukkan dengan probabilitas $0,009<\alpha=5 \%$. Hasil regresi menunjukkan bahwa variabel Pendidikan berpengaruh signifikan terhadap Pendapatan.

Berdasarkan hasil uji t-statistik diketahui bahwa variabel Tenaga kerja berpengaruh signifikan terhadap pendapatan. Hal ini ditunjukkan dengan probabilitas $0,0411<\alpha=5 \%$. Hasil regresi menunjukkan bahwa variabel Tingkat Pendidikan berpengaruh signifikan terhadap Pendapatan

\section{Uji F}

Uji F statistik atau uji simultan untuk melihat bagaimanakah pengaruh Jam Kerja, Modal, Pendidikan, Dan Tenaga Kerja secara bersama-sama terhadap Pendapatan. Uji ini dilakukan dengan membandingka nilai $\mathrm{F}$ hitung dengan $\mathrm{F}$ tabel pada tingkat kepercayaan tertentu atau melihat angka probabilitanya. Hasil yang diperoleh dari uji Fhitung adalah sebesar 30.56444 sedangkan nilai $\mathrm{F}$ table sebesar 3,30.

Dengan demikian berdasarkan tabel 5.6 dapat dilihat bahwa F-hitung > F-tabel $(30.56444>3,30)$ dengan probabilitas sebesar 0,000000. Jadi, nilai F-hitung > F tabel dengan probabilitas < 0,05 (5\%) maka H0 ditolak. Oleh karena ini, dapat disimpulkan bahwa Jam Kerja, Modal, pendidikan dan Tenaga Kerja secara bersama-sama atau simultan berpengaruh signifikan terhadap Pendapatan UKM Sektor Perdagangan di Kota Sungai Penuh.

\section{Koefisien determinan $\left(\mathbf{R}^{2}\right)$}

Nilai Koefisien Determinasi $\left(\mathrm{R}^{2}\right)$ menunjukkan seberapa besar proporsi variabel independen (variabel Jam Kerja, Modal, Pendidikan, dan Tenaga Kerja terhadap 
variabel dependen (Pendapatan). Dari hasil regresi dapat dilihat nilai $\mathrm{R}^{2}$ sebesar $0.533276(52,66 \%)$. Artinya, sebesar 53,32 \% variabel dependen yaitu Pendapatan dipengaruhi oleh variabel independen yaitu Jam Kerja, Modal, Pendidikan, dan Tenaga Kerja. Sedangkan sisanya sebesar 46,68 \% dipengaruhi oleh variabel lain yang tidak termasuk dalam penelitian ini.

\section{Pengaruh jam kerja terhadap pendapatan UKM perdagangan}

Dari hasil regresi diketahui bahwa Jam kerja bepengaruh positif dan signifikan terhadap pendapatan dengan asumsi variabel lain dianggap konstan. Koefisien regresi sebesar 369.490.3 yang artinya jika Jam Kerja meningkat sebesar satu jam maka Pendapatan akan naik sebesar Rp 369.490.3

Jam kerja memiliki pengaruh positif terhadap pendapat. Hal tersebut menunjukkan bahwa jumlah jam kerja pada usaha UKM sektor perdagangan menunjukkan semakin banyak waktu buka atau beroperasional maka semakin besar pendapatan yang diperoleh karena semakin banyak waktu yang dipakai untuk berjualan.

Teori ini didukung oleh penelitian yang dilakukan oleh Anik (2003) yang menyatakan bahwa semakin tinggi jam kerja yang digunakan, maka semakin tinggi pula pendapatan pekerja yang akan diperoleh. Dance Amnesi (2013), Triarya Nugraha (2013) dan Meta Trisnawati (2013) menyatakan jam kerja berpengaruh positif terhadap peningkatan pendapatan. Persamaan dalam penelitian ini menunjukkan penggunaan variabel jam kerja mempengaruhi pendapatan. Berdasarkan hal tersebut maka para pengusaha menambah jam kerja operasional UKM miliknya untuk berdagang, agar dapat meningkatkan pendapatan UKM.

\section{Pengaruh modal terhadap Pendapatan UKM perdagangan}

Dari hasil regresi diketahui bahwa Modal bepengaruh positif dan signifikan terhadap Pendapatan dengan asumsi variabel lain dianggap konstan. Koefisien regresi sebesar 169.509 yang artinya jika Modal meningkat sebesar satu juta maka Pendapatan akan naik sebesar Rp 169.509

Tahap pertumbuhan dan perkembangan usaha dikaitkan Bygrave dan Zacharakis (2010) dengan skala usaha (size) dan tingkat pendapatan (profitabilitas) dari waktu ke waktu. Aktivitas wirausaha dengan pertumbuhan dan keberlangsungan usaha Hubungan juga dijelaskan dalam model penelitian Global Entrepreneur Monitors (GEM). Aktivitas ini selanjutnya mempengaruhi pertumbuhan usaha yang mengindikasikan pertumbuhan ekonomi. Jumlah dan kualitas wirausaha juga akan berpengaruh terhadap tingkat dan kualitas pertumbuhan suatu negara. Makin banyak jumlah wirausaha yang berkualitas ada kemungkinan pertumbuhannya akan semakin tinggi Pambudy (2010).

\section{Pengaruh pendidikan terhadap pendapatan UKM perdagangan}

Dari hasil regresi diketahui bahwa pendidikan bepengaruh positif dan signifikan terhadap Pendapatan dengan asumsi variabel lain dianggap konstan. Koefisien regresi sebesar 382.115.7 yang artinya jika pendidikan meningkat sebesar satu tahun pendidikan maka Pendapatan akan naik sebesar Rp 382.115.7

Pendidikan adalah pionir dalam pembangunan masa depan suatu negara. Karena kemajuan dari sebuah negara dilihat dari besar kecilnya tingkat SDM dari rakyat negara tersebut. Sebab, pendidikan menyangkut pembangunan karakter dan sekaligus mempertahankan jati diri manusia. Berdasarkan hasil statistik variabel pendidikan berpengaruh positif terhadap tingkat pendapatan UKM sektor perdagangan di Kota Sungai Penuh, dan pengaruhnya tidak signifikan terhadap pendapatan. pendidikan 
secara umum pasti akan meningkatkan pendapatan UKM sektor perdagangan karena semakin tinggi tingkat pendidikan seseorang pasti akan mampu meningkatkan pendapatan dari usahanya dengan berbagai macam strategi peningkatan pendapatan baik dari segi marketing, peningkatan pelayanan, atau meningkatkan mutu atau kualitas barang yang diperdagangkan.

Teori ini didukung oleh penelitian yang dilakukan oleh Noor Fitria (2014) yang menyatakan semakin tinggi pendidikan seorang pedagang maka semakin besar pendapatan yang diperoleh. Dance Amnesi (2013), Triarya Nugraha (2013), Ebel Tua (2013) menyatakan pendidikan berpengaruh positif terhadap peningkatan pendapatan. Berdasarkan hal tersebut maka para pengusaha meningkatkan tingkat pendidikan dalam usaha UKM nya dalam berdagang.

\section{Pengaruh tenaga kerja terhadap pendapatan UKM perdagangan}

Dari hasil regresi diketahui bahwa Tenaga kerja bepengaruh positif dan signifikan terhadap Pendapatan dengan asumsi variabel lain dianggap konstan. Koefisien regresi sebesar 595.515 yang artinya jika Tenaga kerja meningkat sebesar satu orang tenaga kerja maka Pendapatan akan naik sebesar Rp 595.515

Teori ini didukung oleh penelitian yang dilakukan oleh Wike Anggraini (2014) yang menyatakan semakin tinggi Tenaga Kerja yang di miliki maka semakin besar pendapatan yang diperoleh. Linda weni (2015), Triarya Nugraha (2017), Laili Riziiq (2016) menyatakan Tenaga Kerja berpengaruh positif terhadap peningkatan pendapatan. Berdasarkan hal tersebut maka para pengusaha meningkatkan tingkat Tenaga kerja dalam usaha UKM nya dalam berdagang.

\section{KESIMPULAN DAN SARAN}

\section{Kesimpulan}

Hasil penelitian menunjukkan bahwa kondisi sosial berpengaruh signifikan terhadap pendapatan UKM perdagangan di Kota Sungai Penuh, Hal ini dapat di lihat dari rata-rata pendidikan pemilik ukm adalah S1 dan S2, Dengan demikan jika semakin tinggi tingkat sosial masyarakat mengindikasikan pendapatan UKM semakin tinggi dan secara tidak langsung pertumbuhan ekonomi juga cenderung semakin baik.

Penelitian ini membuktikan bahwa variabel jam kerja, modal, pendidikan dan Tenaga Kerja berpengaruh terhadap pendapatan UKM perdagangan di Kota Sungai Penuh secara bersama-sama. Keempat variabel tersebut yaitu jam kerja, modal, pendidikan dan Tenaga Kerja berpengaruh terhadap peningkatan pendapatan UKM perdagangan di Kota Sungai Penuh.

\section{Saran}

Bagi Pemerintah Kota Sungai Penuh, diharapkan kepada pemerintah untuk memberi kebijakan kebijakn lebih banyak lagi dalam upaya untuk membantu pertumbuhan UKM daerah sehingga produk mereka bisa bersaing di pasaar global dengan cara lebih rutin lagi mengadakan penyuluhan tentang manajemen keuangan, pengelolaan usaha, serta memberi dukungan materil kepada ukm yang sedang berkembang.

Bagi para pengusaha UKM sebaiknya menambah jam kerja operasional UKM, meningkatkan jumlah modal untuk dapat berproduksi lebih banyak, meningkatkan pendidikan SDM dari Pengusaha dan pekerjanya. Dan meningkatkan jumlah penjualan usahanya. Mengadakan latihan dan sosialisasi terhadap para pekerjanya untuk meningkatkan mutu SDM dan kualitas barang yang diperdagangkan. UKM diharapkan untuk lebih kreatif dan inovatif seperti menyesuaikan barang dagangannya dengan 
selera pasar saat ini serta ikut bersaing dengan menngunakan teknologi yang lebih modern dalam berdagang seperti pemasaran lewat media online, agar kedepannya dalam berdagang agar tetap dapat eksis dibidang usahanya. Dan juga dapat bertahan dari serbuan pasar oleh-oleh modern dan serbuan para pekerja asing serta produk-produk asing.

Bagi peneliti selanjutnya diharapkan menggunakan periode pengamatan yang lebih panjang dengan tujuan memperoleh hasil yang lebih baik. Selain itu diharapkan memasukkan variabel lain yang belum dimasukkan dalam model penelitian.

\section{DAFTAR PUSTAKA}

Anak Agung Ngurah Gede Maheswar. (2018). Analisis faktor-faktor yang mempengaruhi pendapatan UKM sektor perdagangan di Kota Denpasar Universitas Udayana : Bali hal 1

Ariani dan Mohamad Nur Utomo. (2017). Kajian strategi pengembangan usaha mikro kecil dan menengah (UMKM) di Kota Tarakan, Jurnal Organisasi Dan Manajemen, 13-2, 1-6

Bank Indonesia.(2015). Profil bisnis usaha mikro, kecil dan menengah (UMKM). Lembaga Pengembangan Perbankan Indonesia (LPPI): Jakarta

Boediono. (2011). Ekonomi makro, seri sinopsis pengantar ilmu ekonomi. BPFE: Yogyakarta.

Fitria, Aini Noor. (2014). Analisis faktor-faktor yang mempengaruhi pendapatan pedagang tape singkomg di Kota Probolinggo. Universitas Brawijaya. Malang.

Ghozali, Imam. (2016). Aplikasi analisis multivariate dengan program IBM SPSS 21 Update PLS Regresi. Badan Penerbit Universitas Diponegoro: Semarang

Heni, Rahayu Wulandari. (2015). Analisis variabel yang menpengaruhi tingkat pendapatan UKM sentra industri keramik Kelurahan Dinoyo Kecamatan Lowokwaru Kota Malang.

Kuncoro, Mudrajad. (2001). Pengembangan usaha kecil dan kemitraan usaha dalam buku ekonomi pembangunan teori, masalah kebijakan. UPP.AMP YKPN: Yogyakarta

Nurhayani (2012). Analisis pendapatan dan pengeluaran perkapita di Kabupaten Batanghari. Jurnal Paradigma Ekonomika, 1(5).

Rahmawati, Fitri. (2004). Analisis faktor-faktor yang mempengaruhi pilihan karir mahasiswa akutansi sebagai akuntan publik. Skripsi S-1. Akutansi. UNS.

Simamora. (2010). Gender, tingkat pendidikan dan lama usaha sebagai determinan penghasilan UMKM Kota Surabaya, UMKM : Surabaya

Sugiyono. (2014). Metode penelitian manajemen. Bandung: Alfabeta.

Sukirno, Sadono. (2016). Makroekonomi Teori Pengantar. Edisi 3. Jakarta: Raja Grafindo Persada (Rajawali Press).

Sulistyo (2011), Pengembangan usaha kecil dan menengah dengan basis ekonomi kerakyatan di Kabupaten Malang, Jurnal Ekonomi Modernisasi, 6(1),

Sujarweni, Wiratna (2015). Metodelogi penelitian bisnis \& ekonomi Pustaka Press: Yogyakarta

Trisnawati, Meta. (2013). Pengaruh modal kerja, tenaga kerja, jam kerja terhadap pendapatan nelayan tradisional di Nagari Koto Taratak Kecamatan Sutera Kabupaten Pesisir Selatan. Program Studi Pendidikan Ekonomi STKIP PGRI Sumatera Barat. Padang.

Wibowo, Singgih. (2007). Petunjuk mendirikan perusahaan kecil. Edisi Revisi. Penebar Swadaya: Jakarta. 